\title{
The Implementation of Hypertext-based Learning Media for a Local Cultural Based Learning
}

\author{
Made Windu Antara Kesiman and Ketut Agustini \\ Jurusan Pendidikan Teknik Informatika, Fakultas Teknik dan \\ Kejuruan, Universitas Pendidikan Ganesha, \\ Singaraja, Bali, Indonesia
}

dekndu@yahoo.com eghee2006@gmail.com

\section{Executive Summary}

By studying and analyzing thoroughly the aspects of Indonesian culture, we may find many concepts of local wisdom that have been practiced in daily life of Indonesian people that can be beneficial for Information Technology study. Subak is a Balinese organization of irrigation systems, and is one example of local wisdom known widely in the world. Subak, as one of the greatest Balinese cultural heritages, is the backbone of Balinese rice cultivation. The aim of this research is to develop and to implement a hypertext-based learning media for local cultural based learning with a case study in the Computer Operating System course for undergraduate students of Jurusan Pendidikan Teknik Informatika, Fakultas Teknik dan Kejuruan, Universitas Pendidikan Ganesha, in Singaraja Bali, Indonesia, based on the concept of Subak. This research starts with exploration of the local wisdom concept "Subak" to collect a specific local cultural based teaching material. We found that Subak is not only a religious and social based cultural heritage, but it manages a deep and complex concept of limited resource sharing, similar with a modern computer. Seeing the characteristics and organizational structures of Subak system that are complete, solid, and effective, it is not impossible to explore various underlying concepts of this local wisdom that might prove beneficial for the field of information technology. Built from the various aspects and components of a complete life, Subak runs a quite complex operational procedure, which is a close analogy to an operating system run by a computer. The concept of Subak's organizational structure as a complex system of regulation for the collective interests provides the basis of early studies for exploring the concept of an operating system. Subsequent to analysis of Operating Systems course syllabus and the analysis of Operating System concepts based on local wisdom of Subak that has been generated in previous studies, it is necessary to build software that is capable of implementing such materials with an attractive appearance, with the ability to present the documents in an unstructured domain (a non sequential / nonlinear) and, at the same time, is easily affordable (accessible), so that it can cover the entire complex material and it can follow the user, according to the concept of hypertext. A hypertext-based learning media based on Subak

Material published as part of this publication, either on-line or in print, is copyrighted by the Informing Science Institute. Permission to make digital or paper copy of part or all of these works for personal or classroom use is granted without fee provided that the copies are not made or distributed for profit or commercial advantage AND that copies 1) bear this notice in full and 2) give the full citation on the first page. It is permissible to abstract these works so long as credit is given. To copy in all other cases or to republish or to post on a server or to redistribute to lists requires specific permission and payment of a fee. Contact Publisher@InformingScience.org to request redistribution permission. is then developed in this research based on the study of Subak as an integrated operating system. It is necessary to develop software which satisfies three criteria - 1) capable of implementing the materials in attractive appearances, 2) able to present the documents in an unstructured domain (a non sequential / nonlinear), and 3 ) easily affordable (accessible) so that it can cover the entire complex material and follow user ac- 
cording to the concept of hypertext. This paper also proposes an experimental research design plan in the actual classroom learning process that will be conducted in order to assess the effectiveness of the local cultural based teaching material in improving students' motivation and achievement. We can adopt and assimilate the concept of Subak into a specific teaching material to facilitate our local cultural based learning process in order to improve motivation and achievement of students. The study of the concepts of local wisdom of Indonesian culture must be more focused on the development of education, such as in the field of technology which is still not a major concern of the world community. Local cultural based learning should be made on educational curriculum for maintaining pluralism in Indonesia.

Keywords: hypertext, learning media, local cultural, subak, operating system

\section{Introduction}

Subak is a Balinese organization of irrigation systems, and is one example of local wisdom known widely in the world. Subak, as one of the greatest Balinese cultural heritages, is the backbone of Balinese rice cultivation. According to Subagia and Wiratma in their study in 2006, there were some aspects of local genius potentials of Balinese (Hindu) people, which are relevant to the development of modern education. These local genius potentials were 1) the conception of the level of learning, 2) the conception of learning discipline, 3) the conception of teachers (guru), 4) the conception of the method of teaching, and 5) the conception of the method of learning. Based on these findings, it was suggested that the existence of the local genius should be taken into account in developing the concepts of a cultural-based education (Subagia \& Wiratma, 2006). Sarna and Suastra (2008) proposed from their study a new conceptual cultural based model for education in Bali. This model consists of four main components of educational model: 1) standard of competency, 2) cultural themes to support the standard of competency, 3) learning approach to implement the standard of competency, and 4) method of assessment to evaluate the cultural based model for education. The result of their study showed that this new cultural based model for education can improve the learning quality and learning outcome of the students.

The exploration of Subak organization system was more commonly done in terms of socioeconomic, water management and rice cultivation, and social interaction between subak communities (Sukarata, 1999). The concept of Subak's organizational structure as a complex system of regulation for the collective interests provides the basis of early studies to explore more deeply the concept of an operating system. We found that Subak is not only a religious and social based cultural heritage, but it manages a deep and complex concept of limited resource sharing, similar with a modern computer. Seeing the characteristics and organizational structures of Subak system that are complete, solid, and effective, it is not impossible to explore various underlying concepts of this local wisdom that might prove beneficial for the field of information technology. Built from the various aspects and components of a complete life, Subak runs a quite complex operational procedure, which is a close analogy with an operating system run by a computer.

The aim of this research is to develop and to implement a hypertext-based learning media of local cultural based learning. This research takes a case study in the Computer Operating System course based on the concept of Subak. This research explores and analyzes the values of local wisdom inside Subak system and organization, by examining Subak as an integrated technological system of a computer operating system, and also the implementation of local cultural based learning process in the real classroom learning process. The originality of this research lies on the exploration and the analysis of the concepts of local wisdom in system and organization of subak related to technology field, particularly for the concept of computer operating system. 


\section{Exploration of the Concepts of Local Wisdom of Subak}

\section{What is Subak?}

In the Indonesian island of Bali, rice farmers form cooperative associations called Subak, averaging 100 farmers working on less than 50 hectares of irrigated rice fields (Falvo, 2000). Subak is a socio-religious organization responsible for irrigation management and religious activities within a defined geographical area. Every Subak has rules that are developed over a long period of time. They have been codified in a set of laws called awig-awig. These laws regulate rights and duties among the members of the Subak. Such rights and duties include public obligations, regulations concerning land and water use, legal transactions of land transfer, and collective religious ceremonies (Lorenzen, 2006).

\section{The Concept of an Operating System as a Local Wisdom of Subak}

As a system, subak is a liaison between the farmers (owners and tillers of the rice fields) with the physical infrastructure of irrigation networks in the area of subak (Figure 1). Subak is the manager of all resources contained in subak area and provides a set of services for members of the subak. The main goal of those services is the easy and the comforting use and utilization of existing resources in the area of subak.

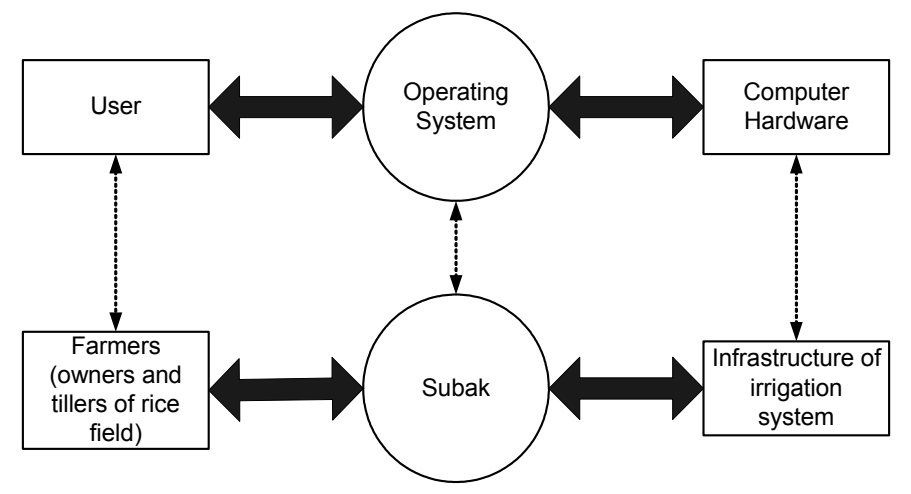

Figure 1. Concept of operating system inside the system of subak

\section{Subak components and services}

As an irrigation system, subak owns and manages a network of irrigation from the same water source. Like a computer, subak was mostly supported by three main components: the hardware (facilities and irrigation infrastructure), the software (the processes undertaken since planting the seed to harvest, along with a series of religious ceremonies performed), and users (the members of subak in concerned). Three main parts, such as the input devices, the process equipment, and the output devices, are also contained in the concept of system of subak. Subak as a physical unit has a subsystem of artifacts which also serve as input devices, process equipment, and output devices. Control access to resources should also be done on a subak system. The basic services of an operating system can be found commonly in each of the subak, such as Activity Management, Resource Management, Input and Output System Management, Protection System, and Distributed System between several subak (Figure 2). 


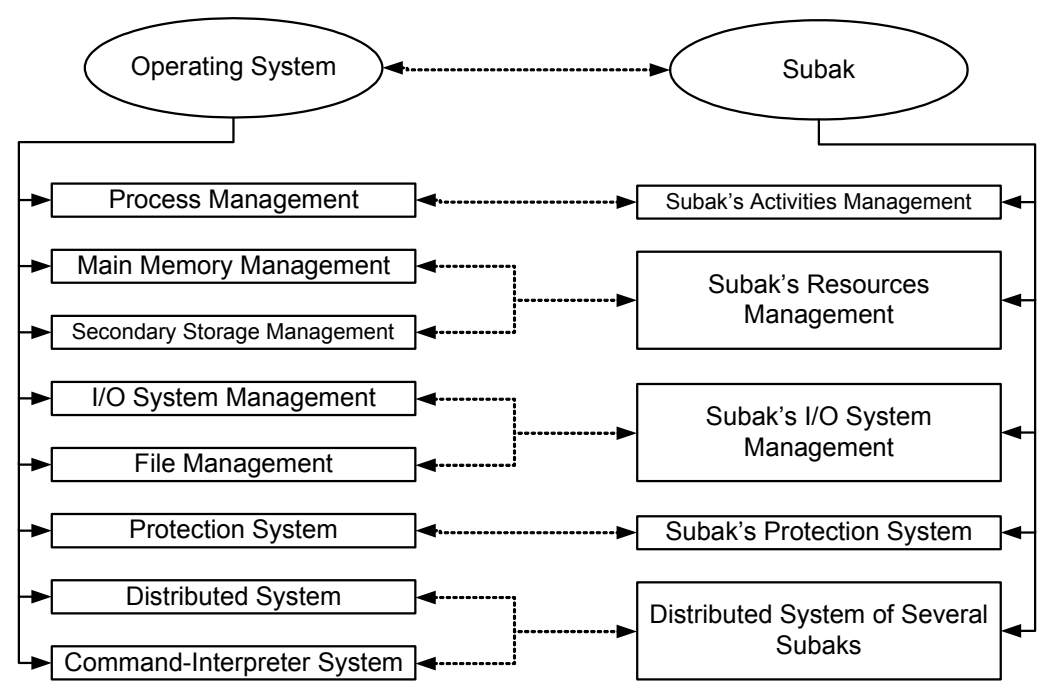

Figure 2. Subak services

Subak members do not directly access the resources of subak. System or device or Subak rules should provide mechanisms to access resources on behalf of Subak members. In this case, Subak acts as a resource allocator, for allocating resources to some of its members or jobs that run at the same time. Pekaseh or the head of Subak is responsible for managing the distribution of water to be fair and equitable for all Subak members. For a larger Subak (usually called subak gede), Sedahan is responsible for synchronization when there is a conflict of water usage among Subak members. The flow of water from the dam should be governed by the gate controller so that it is in accordance with the agreements that have been made by all members. Interruption is an important part of computer architecture. This mechanism is also applied in the process of water distribution in Subak system.

During the period of the growing season until the harvest season, the water distribution process will be conducted in accordance with earlier agreements of all Subak members. However, in actual practice, some members may complain to Subak for problems in distribution of water they received. Like an operating system, system organization of subak is also responsible for activities related to collective management of resources such as keeping track and distribution of water usage, selecting the cropping activities and religious ceremonies, and arranging the process of borrowing/transfer of land and water among Subak members (Figure 3).

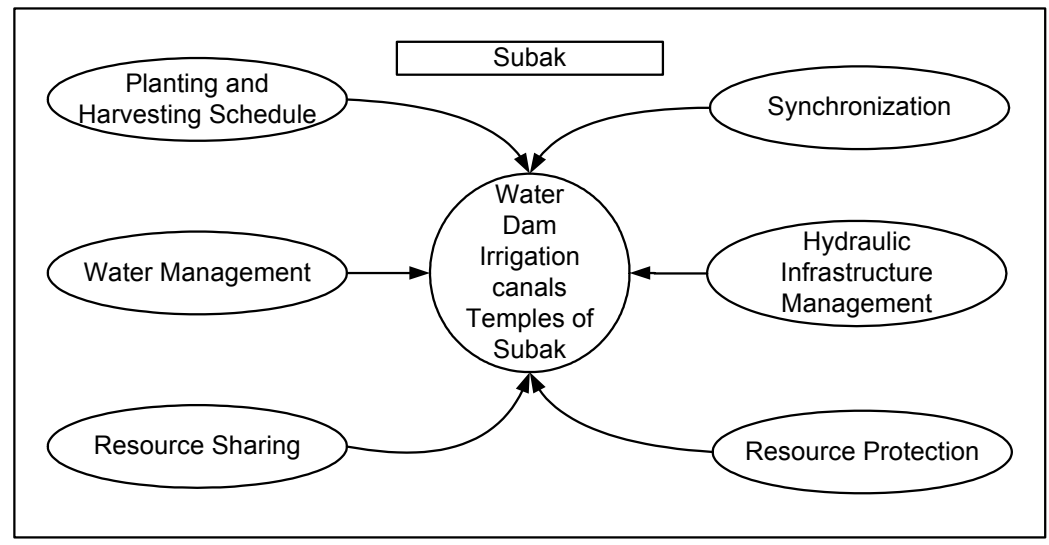

Figure 3. Resources management of subak 
In the concept of the operating system, the process is a program being executed. While in an organization system of subak, a process is associated with all activities undertaken by all members. As mentioned earlier, Subak runs various types of activities, but the main activity as an agricultural organization is, of course, rice-planting activities. The entire activity requires collective resources which include water, irrigation canals, and temples of subak.

Subak provides a mechanism for synchronization of different activities and also provides a mechanism for communication among its members to prevent internal conflict. On process management, Subak is responsible for activities such as scheduling and cropping patterns of all members, controlling the process of planting and harvesting from all rice fields, providing a mechanism for synchronization of planting and harvesting schedules, and also providing a mechanism for communication between one member and others in the event that conflict of agricultural activities occurs.

Two or more Subak organizations can come together to form a larger subak. In this distributed system of several Subaks lies a lot of concept of local wisdom as a quite complex operating system. A number of ceremonies are performed in planting time or to anticipate extraordinary events such as pest attacks. In a distributed system, Subak tries to maintain the coherence and consistency of water flow that becomes more complex. A rice field area could receive water input from several sources originating from different regions of Subak. The process of negotiation and compromising of water distribution will be made among Sedahan of each Subak region. Besides the need to calculate the debit of water received from irrigation channels of Subak itself, the quantity of water received from other surrounding Subaks must also be taken into account.

Subak system also provides services to all members of irrigation facilities and infrastructures within its region. Services provided by Subak in an irrigation system are as follows. The first service is planting program (as program execution). Subak should be able to implement the entire planting program that is planned, including a whole series of religious ceremonies to be done. The second one is setting and maintenance of irrigation facilities and infrastructure (as I/O operations). Subak is obliged to arrange everything about the usage of facilities and irrigation infrastructure. Farmers themselves can not manipulate the use of irrigation facilities, without any agreement among all Subak members, in accordance with the rules stipulated in awig-awig of Subak. The third service is Subak as a media of communication among its members. Subak serves as a bridge of communication among its members, for all activities that will be run by Subak members. The fourth one is anticipating the conflict and the searching for solutions (as error detection). Subak should be able to provide solutions for conflicts arising within its territory. The fifth service is allocating the irrigation water resources (as resource allocation). And the last one, the sixth service is protecting the distribution process and the use of irrigation water resources (as a protection system).

Similar to an operating system, Subak also has the main objective as follows. Leisure - Subak basically provides comfort for all members in the use of limited resources but common in the area concerned. Efficiency - the use and utilization of Subak resources should be done as efficiently as possible. Evolving - systems and organization of Subak must be built to enable and to facilitate the development, testing, and filing the new systems. These objectives are obvious from the characteristics of awig-awig of Subak which is highly flexible; even sometimes tending to be nonformal agreement among Subak members.

Subak provides services for the proper use of all resources in the operation of an irrigation system. Subak is not only a religious and social based cultural heritage, but it is also a real system supported by a deep and complex concept of limited resource sharing, similar with a modern computer (Kesiman, 2011a). 


\section{Teaching and Learning Materials}

This research was conducted in Jurusan Pendidikan Teknik Informatika, Fakultas Teknik dan Kejuruan, Universitas Pendidikan Ganesha. Following a study on the exploration of Subak as an integrated operating system, an Operating System Learning Media based on value of local wisdom of Subak is developed in this research. Based on the syllabus of Operating System course, the learning media developed in this research consists of six chapters. Each chapter is described and associated from two points of view: the concept of operating system on a computer and the concept of operating system on Subak. The details of the specific content for those six chapters of the Operating System Learning Media based on value of local wisdom of Subak are:

1. Basic Components and Structure of Computer System:Components of Computer System (+ Components of Subak),Operations of Computer System (+ Structure of Modern Subak),Storage Structure (+ Subak Reservoir System), Storage Hierarchy (+ Subak Reservoir Hierarchy and Location), Caching, Coherency and Consistency (+ Water Distribution Coherency and Consistency within Subak), Network Structure (+ Subak Organization Structure and Hierarchy), Local Area Networks, Wide Area Networks (+ Structure of Subak Gede)

2. Basic Concepts of Operating System: Definition of Operating System (+ Abstraction of an Irrigation System), Targets of Operating System (+ Targets of Subak), Components of Operating System (+ Components of Subak), Process Management (+ Subak Activities Management), Main Memory Management (+ Subak Resources Management)

3. File Management: Input Output System Management (+ Subak I/O System), Secondary Storage Management (+ Subak Resources Management), Networking (+ Subak Gede Structure), Protection System (+ Water Protection in Subak), Command Interpreter System, Operating System Services (+ Subak Services), Process and Process Management (+ Subak Activities Management), Definition of Process (+ Type of Activities in Subak), Process Scheduling (+ Cultivation and Harvest Scheduling), Process Interaction, Thread, CPU Scheduling (+ Water Distribution Scheduling and Subak Interdependency), Priority and Multiprocessor, Real Time System

4. Synchronization and Deadlock: Background of Synchronization (+ Synchronized Cultivation in Subak), Critical Section, Semaphore, Bounded Buffer, Readers/Writers and Dining Philosophers Problem (+ Water Negotiation Procedure in Subak), Critical Region and Monitor, Deadlock (+ Water Usage Conflict in Subak), Graph Diagram (+ InterSubak Irrigation Management)

5. Memory Management: Memory Management (+ Water Distribution Management in Subak), Memory Allocation (+ Water Distribution Measure in Subak), Paging, Paging Table Structure, Segmentation, Virtual Memory and Demand Paging, Demand Paging Aspect : Process Creation, Basic Concept of Page Moving, Algorithm of Page Moving, Frame Allocation Strategy

6. Input and Output Device (+ Inlet Outlet System in Subak): Introduction, Input and Output Device (+ Physical Infrastructure of Subak), I/O Interface Application, I/O Streams, Disc Management, SWAP and RAID, Tertier Storage

\section{Implementation of Hypertext-based Learning Media}

Subsequent to analysis of Operating Systems course syllabus and the analysis of Operating System concepts based on local wisdom of Subak that has been generated in previous studies (Kesiman, 2011a), it is necessary to build software that is capable of implementing such materials with an attractive appearance, with ability to present the documents in an unstructured domain (a 
non sequential / nonlinear), and at the same time, is easily affordable (accessible), so that it can cover the entire complex material and it can follow the user, according to the concept of hypertext.

Technically, this software must be able to:

1. Show the hyperlink for Standard of Competency and Result Indicator for all learning material of Operating System course, based on the curriculum of Jurusan Pendidikan Teknik Informatika, Fakultas Teknik dan Kejuruan, Universitas Pendidikan Ganesha, as a result of the analysis of the value of local wisdom of Subak.

2. Show all teaching and learning materials of Operating System course, based on the curriculum of Jurusan Pendidikan Teknik Informatika, Fakultas Teknik dan Kejuruan, Universitas Pendidikan Ganesha, as a result of the analysis of the value of local wisdom of Subak, which has been generated in previous studies. The structure of hyperlink will be used to present this learning material, for every chapter and sub chapter.

3. Show the hyperlink in every page of learning media, to guide user to navigate forward and backward, to the next page or to the previous page of learning media easily.

4. Show the glossaries of terms in the concept of Operating System and Subak, to help user in finding the definition of any term regarding the relation between the two different concepts in this learning media easily.

5. Show the hyperlink for every scheme or picture contained in this learning media, to guide user in finding the explanation of every diagram, scheme, or picture regarding the concept of Operating System and Subak easily.

6. Show the hyperlink of Questions and Answers as the exercises for students in regards to the concept of Operating System and Subak.

The hypertext-based learning media is a web-based application, which enables any users to interact with the learning materials through the structure of hyperlink. The context diagram and data flow diagram as a software functional model for the learning media is used to show the interaction between user and the hypertext-based learning media (Kesiman, 2011b). The hypertext-based learning media is designed in five main processes and is implemented in 13 main modules. Figure 4 shows the implementation of the interface design of the hypertext-based learning media.
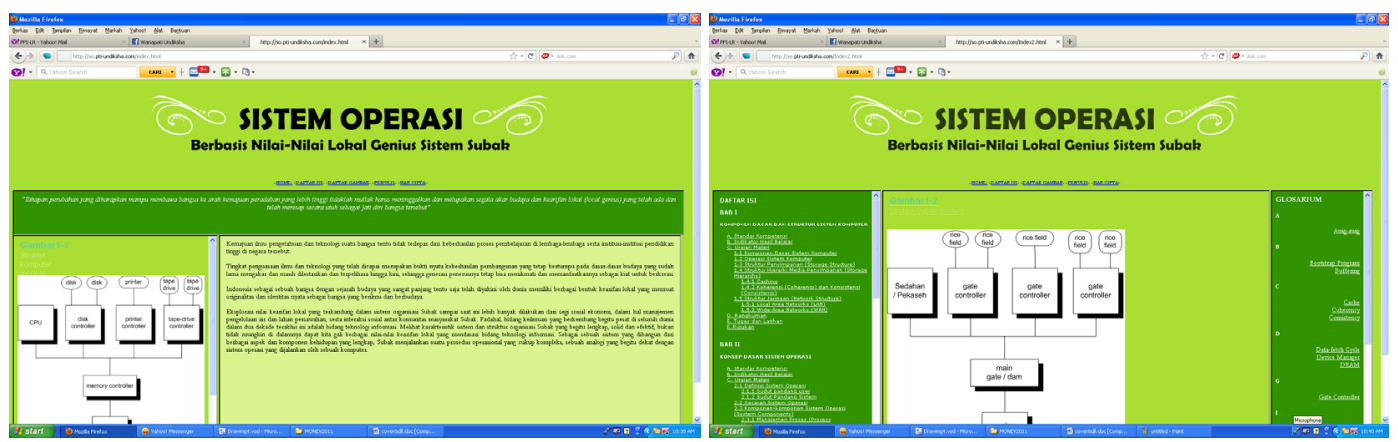

Figure 4. The main page and main menu of hypertext-based learning media (screen shot)

\section{Future Research}

An experimental research design in the real classroom learning process will be conducted in order to analyze the effectiveness of the local cultural based teaching material in improving student's motivation and achievement. Experimental design process (quasi-experimental research design with post test design) is held to verify the research hypotheses. This experiment will be held in a 
real classroom learning process. In accordance with the hypothesis proposed in this study, the independent variable is type of teaching and learning media (learning module or hypertext-based learning media) that is used in the real classroom learning process for the Operating System course. The control class will use the pure Operating System teaching material (learning module), and the experimental class will use the Operating System teaching material with hypertext-based learning media, based on local wisdom values of Subak developed in this study. Students undergo the study naturally. There will be no specific procedures to ask the participants to do the study. All students included in the samples of this research will already be registered in the university, and they will formally take Operating System course, which is one of the compulsory subjects in the curriculum of Jurusan Pendidikan Teknik Informatika, Fakultas Teknik dan Kejuruan, Universitas Pendidikan Ganesha, for bachelor degree program, in one particular class.

The dependent variables measured in the study are (1) students' achievement in Operating System course, (2) students' motivation in Operating System course, and (3) students' response in Operating System course with the development and the use of hypertext-based learning media based on local wisdom values of Subak. Students' achievement will be measured from the experimental and control group. Students' motivation and students' response will only be measured from the experimental group. The data of research will be consisting of data about students' motivation, students' response, and students' achievement in the learning process. Each data will be collected through questionnaires and the evaluation test for students. Statistical descriptive analysis conducted on the data of students' motivation and students' response, whereas the $t$-test will be conducted on the data of students' achievement.

\section{Conclusions and Recommendations}

The development of information technology today is certainly a potential for the development of national education and culture. However, modernization should reform many past life aspects of a society to suit the needs of the present and future, without destroying the elements of originality. This is the public expectation of an ongoing development today. The hypertext can be developed and implemented to improve the motivation and passion of students in the learning process, to develop the ability of learners in interacting directly with the environment and other learning resources, to allow students or learners in learning based on their individual ability and personal interest, and to allow students or training participants in measuring or evaluating their own learning results. Hypertext application facilitates the learning process. Technology of hypertext can be designed to reflect the cognitive process of the competency of a student in a specific level.

By exploring the technological aspects of Subak as an operating system, we found that Subak is not only a religious and social based cultural heritage, but it is also a real system supported by a deep and complex concept of limited resource sharing, similar with a modern computer. As such, we can adopt and assimilate the concept of Subak into a specific teaching material to facilitate our local cultural based learning process in order to improve motivation and achievement of students. The study of the concepts of local wisdom of Indonesian culture must be more focused on the development of education, such as in the field of technology which is still not a major concern of the world community. Local cultural based learning should be made on educational curriculum for maintaining pluralism in Indonesia. 


\section{References}

Falvo, D. J. (2000). On modeling balinese water temple network as complex adaptive systems. Human Ecology , XXVIII (4).

Kesiman, M. W. A. (2011a). Improving student's motivation and achievement by implementing a local cultural based learning. In Z. Sakhiya, I. M. Arsana, \& M. Ramadewi (Eds.), Education Count! (pp. 169-193). Melbourne: PPIA.

Kesiman, M. W. A. (2011b). Simulation-based CAI of list data structure for the learning process of design and analysis of algorithm. Prosiding Seminar Internasional Teknologi Informasi dan Pendidikan, Padang, Indonesia, 473-478.

Lorenzen, S. (2006). "I am just borrowing water, but I will return it in an hour". The interdependance of informal and formal institutions in balinese irrigation management. 11th Biennial Conference of The International Assocation For The Study Of The Commons, Ubud, Indonesia.

Sarna, K., \& Suastra, I. W. (2008). Model pendidikan lintas kultur terintegrasi berbasis kompetensi (PLKTBK) SD/MI dan SMP/MTs di wilayah Bali [Competency-based integrated cross-cultural education models (PLK-TBK) SD/MI (elementary school) and SMP/MTs (junior high school) in Bali]. Konvensi Nasional Pendidikan Indonesia, Denpasar, Indonesia, 1112-1134

Subagia, I. W., \& Wiratma, I. G. L. (2006). Potensi-potensi kearifan lokal masyarakat Bali dalam bidang pendidikan [Balinese potential local wisdom in education]. Jurnal Pendidikan dan Pengajaran, XXXIX (3), 552-565

Sukarata, M. (1999). Pengenalan dan pemahaman local genius menghadapi era globalisasi di Indonesia [Recognition and understanding of the local genius in the era of globalization in Indonesia]. Nirmana, $I(1)$.

\section{Biographies}

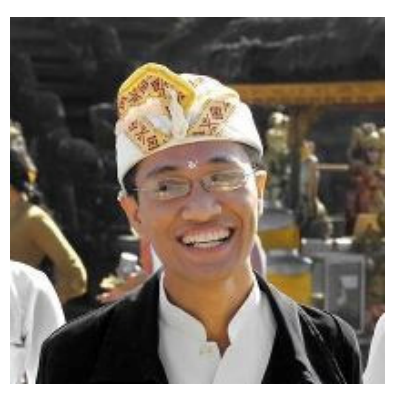

Made Windu Antara Kesiman was born on November 11th 1982 in Singaraja, Bali, Indonesia. He got a bachelor degree from Institut Teknologi Bandung (ITB), Indonesia, in 2004, majoring in Informatics. In 2005, he received a master scholarship, under the BGF (Bourse de Gouvernement Francais) program, from the French government. He got a master of science degree from Universite de La Rochelle, France, in 2006, majoring in Informatics. He is now a lecturer in Jurusan Pendidikan Teknik Informatika, Fakultas Teknik dan Kejuruan, Universitas Pendidikan Ganesha, in Singaraja, Bali.

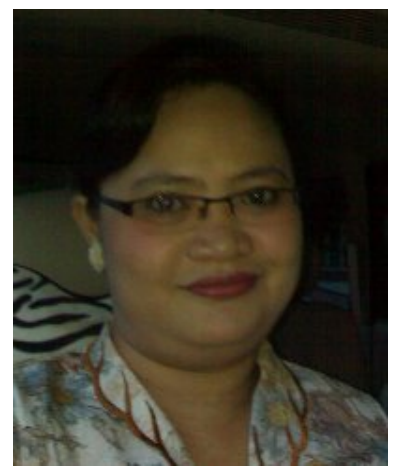

Ketut Agustini was born on August 1st 1974 in Singaraja, Bali, Indonesia. She got a bachelor degree from Universitas Airlangga, Indonesia, in 1998, majoring in Mathematics. She got a master of science degree from Institut Pertanian Bogor, Indonesia, in 2006, majoring in computer science. She is now a lecturer in Jurusan Pendidikan Teknik Informatika, Fakultas Teknik dan Kejuruan, Universitas Pendidikan Ganesha, in Singaraja, Bali. 